\title{
Islamic Insurance in Bangladesh: Performance, Problems and Prospects
}

\author{
Serajul Islam \\ Associate Professor \\ Department of Business Administration \\ International Islamic University Chittagong \\ Kumira, Sitakunda, Chittagong-4318, Bangladesh \\ E-mail Address:serajulislamiiuc@gmail.com \\ Mobile Number: 088-01711448142 \\ Tania Sultana \\ Lecturer \\ Department of Business Administration \\ International Islamic University Chittagong \\ Kumira, Sitakunda, Chittagong-4318, Bangladesh \\ E-mail Address:taniasultanaiiuc@gmail.com
}

Received: December 9, 2018 Accepted: December 19, 2018 Online Published: December 30, 2018

\begin{abstract}
Islamic insurance companies can provide efficient takaful services to the nation if they had the opportunity to work as a sole system in an economy. But in Bangladesh, Insurance companies are operating their activities under the dual framework both of conventional and Islamic framework monitored by the Insurance Development and Regulatory Authority (IDRA). This paper focuses key issues, technical issues and Challenges facing the Takaful industry in Bangladesh. Key Issues and Challenges are Scarcity of human resources with both insurance and Shariah expertise, Lack of standardization in the industry that is due to Shariah interpretations, diverging regulatory approaches and the lack of centralized regulations and shortage of suitable assets. In addition, there are various technical issues within the takaful industry, which may be relevant in the valuation and risk management of takaful business. Some of the technical issues are riba, issues around retakaful, too much stress on profit distribution and lengthy procedure in claim's settlement. Some main benefits of Islamic insurance practices in Bangladesh are mobilization of savings, islamically approved (Halal) investment opportunity, opportunity to perform good deeds and to do charitable works, and distribution of Zakat.
\end{abstract}

Keywords: Islamic insurance, Shariah, takaful, challenges, regulation and zakat.

1. Introduction

Islamic Insurance companies play a vital role in improving resource allocation, mobilizing savings, creating investment opportunity in islamically approved (Halal) area, creating opportunity to perform good deeds and to do charitable works, lowering cost of capital via economies of scale and providing risk management and liquidity. The insurance companies are performing the functions as takaful underwriting to provide equitable and fair risk-sharing schemes, and indemnification, saving substitution and capital formation, investment and financial development. As per IDRA (Insurance Development \& Regulatory Authority Bangladesh), there are 62 insurance companies operating in Bangladesh. Among them 56 are conventional insurance companies and 6 are Islamic insurance companies. The Parliament of Bangladesh on 03 March 
2010 passed two insurance laws in a bid to further strengthen the regulatory framework and make the industry operationally vibrant. The new laws, came in to effect on 18 March 2010, are Insurance Act 2010 and IDRA(Insurance Development \& Regulatory Authority Bangladesh) 2010. Now the companies are operating their activities under the Insurance Act 2010 and IDRA (Insurance Development \& Regulatory Authority Bangladesh) 2010. Takaful is a type of Islamic insurance, where members contribute money into a pooling system in order to guarantee each other against loss or damage. It is based on Islamic religious law, and explains how it is the responsibility of individuals to cooperate and protect each other. This is because insurance may have a place in Shari'ah, if it is approved by the Shari'ah practices based on shared responsibility, mutual co-operation and solidarity, to safeguard one against a defined risk and which go against the riba (interest), al-maisir (gambling) and al-gharar (uncertainty) principles, that are outlawed in Shari'ah (Ali, 2009).

2. Objectives of the study

The objectives of the study are as follows:

- To know the present scenario of Islamic insurance in Bangladesh

- To analyse the performance of Islamic insurance industry

- To present the growth analysis of the takaful industry

- To find out the benefits of Islamic insurance

- To identify the pitfalls and suggest some policy measures for the development of takaful industry for the years ahead.

\section{Methodology}

To make the effort a success, researcher has collected both primary and secondary data. Primary data have been collected through pre-designed questionnaires with interview schedule with 40 personnel associated with takaful operations. Deliberate sampling has been used to involve purposive or deliberate selection of participatory branches of the takaful industry for constituting a better representative. The study is mainly based on secondary data. Secondary data have been collected from annual reports of Islamic insurance companies, different publications regarding takaful operations, different books, and national and international research articles and websites. The data thus collected have been tabulated first manually. Then they have been analyzed by employing both statistical and financial techniques such as percentage, diagrammatic \& graphical presentation, average $(\mu)$, standard deviation (o), coefficient of variation (C.V.) and financial ratios.

4. The Genesis of Islamic Insurance Operations in Bangladesh

On August, 1977, Faisal Islamic Bank was registered as a public limited company under the Sudanese Company Act-1925. When Faisal Islamic bank was established, the bank authorities initiated studies on the establishment of a co-operative insurance company. In this respect the opinion of the bank's Shariah Supervisory Board (SSB) was sought. The SSB studied the scheme at the first meeting. Studies continued and several steps followed. The Memorandum of Association and Article of Association were prepared by the Faisal Islamic Bank Authorities. The SSB proposed some amendments which were implemented. The SSB ensured that the scheme was sound from a Shariah point of view as well as feasible from a practical point of view. Therefore, the Islamic Insurance Company Ltd. Sudan was incorporated as a Sudanese Public Company (under the Companies Act 1925) in January, 1979. This is the first ever insurance company established in the world to transact business according to the Islamic Shariah. In Bangladesh, the first general insurance (takaful) company (Islamic Insurance Bangladesh Limited) based on the Islami Shariah, belonging to $3^{\text {rd }}$ Generation was registered and established under the Bangladesh Company Act, 1994 and the Bangladesh Insurance Act, 1938 on $29^{\text {th }}$ December,1999 to transact all sorts of general Takaful business. Now, six full-fledged Islamic Insurance Companies are operating their insurance services under the rule of shariah. The six Islamic insurance companies are as follows:

- Islamic Insurance Bangladesh Limited

- Fareast Islami Life Insurance Company Limited

- Takaful Islami Insurance Limited

- Prime Islami Life Insurance Limited

- Padma Islami Life Insurance

- Islamic Commercial Insurance Company

4.1 Islamic Insurance Bangladesh Limited

Islamic Insurance Bangladesh Limited (IIBL) is the first general insurance (takaful) company based on the Islami Shariah in Bangladesh. It is a $3^{\text {rd }}$ Generation Company. IIBL was registered and established under the Bangladesh Company Act, 1994 and the Bangladesh Insurance Act, 1938 on $29^{\text {th }}$ December, 1999 to 
transact all sorts of general Takaful business. The company started functioning from $1^{\text {st }}$ January, 2000. The amount of claim settlement of the company during the past years up to 2008 is TK.182 million. The company has 38 branches at the different places of the country. The premium income, total assets and total reserve of the company stood at TK. 23.26 crore, tk. 23.78 crore and tk. 8.18 crore in 2008 respectively. IIBL has an eight-member Shariah Council (Shariah Advisory Board) constituted with eminent Islamic scholars, Shariah experts and Legal experts for supervising the affairs/functions of the company in the light of Shariah. The Credit Rating Information and Services Ltd. (CRISL) has graded the Company rating claim paying ability to BBB+ (Triple 'B' Plus). The company has some valued customers including Beximco Textile, Korea Trade Center, Dayeu Bangladesh Ltd., Shining Shadow, Novert is, Korean Embassy, Akij Group, Abul Khair, IbnSina etc. which are the most prominent business organizations in Bangladesh.

4.2 Fareast Islami Life Insurance Co. Ltd.

The Fareast Islami Life Insurance Company Limited is a third generation life insurance company incorporated on 29 May, 2000 under the Companies Act, 1994 as a public limited company. The company's paid up capital was Tk.281.36 million as on October 31, 2011.The company has already opened 1012 Offices including 10 Divisional offices, 38 full-fledged Service Centers and 112 Zonal Offices in different places all over the country. The life insurance fund of the company stood at Tk.13,529.51 million as on December 31, 2010. The company has a thirteen-member Shariah Council (Shariah Advisory Board) constituted with eminent Islamic scholars, Shariah experts and Legal experts for supervising the affairs/functions of the company in the light of Shariah. Credit Rating Information and Services Limited (CRISL) has assigned A+ (pronounced as 'single A plus').

4.3 Takaful Islami Insurance Limited

Takaful Islami Insurance Limited was established in 2002. Paid-up capital of the company is Tk.60.00 million as 31st December 2007. Total Asset as of 31st December, 2007 stood at over Tk. 2026.86 million. Company's investment portfolio's position in brief, as of December, 2007, stood as Govt. Bond Tk. 90,00,000.00, Shares (at cost)Tk.2,12,10,243.00, TDR/FDR Tk. 8,17,00,000.00, Fixed Assets Tk. $64,34,004.00$ i.e. Total Tk. 11,83,44,247.00. The company has settled claims of over Tk. 1307.52 lac since it started operation in 2001 till 2007. Company's gross premium income, reinsurance cession and net premium retention for the year 2007 were TK 1626.76 lac, 619.69 lac and 1007.07 lac respectively. The company has an eight-member Shariah Council (Shariah Advisory Board) constituted with eminent Islamic scholars, Shariah experts and Legal experts for supervising the affairs/functions of the company in the light of Shariah. The Company has 91valued customers which are the important and influential business organization in Bangladesh. Among the valued customers some are Islami Bank Bangladesh Ltd., AlArafa Islami Bank Ltd., Sahjalal Islami Bank Ltd., EXIM Bank Ltd., Islamic Fiance \& Industrial Ltd., M/S. IBN SINA Trust, M/S. IBN SINA Pharmaceuticals Ltd., M/S. Saiham Jute Mills Ltd., M/S. Annesha Style Ltd. , M/S. R. B. Group of Company (Walton), M/S. Crown Fashion, M/S. Hamdard Laboratories, M/S. Mithapur Textiles Ltd. Etc.

4.4 Prime Islami Life Insurance Limited

Prime Life Insurance Company Ltd. was incorporated in July-2000. It was converted into an Islamic Company in the name of Prime Islami Life Insurance Ltd. in April-2002. The company's paid-up capital is Taka 158 million. The Credit Rating Information and Services Ltd. (CRISL) have graded the Company rating claim paying ability to A+. It got ISO certification on the $6^{\text {th }}$ October, 2006. The company has a fifteen-member Shariah Council (Shariah Advisory Board) constituted with eminent Islamic scholars, Shariah experts and Legal experts for supervising the affairs/functions of the company in the light of Shariah.

\subsection{Padma Islami Life Insurance Limited}

Padma Islami Life Insurance Limited incorporated as the Insurance Company in the country on the $26^{\text {th }}$ April, 2000. It was converted into Islami Company on the $31^{\text {st }}$ January, 2007. It's paid-up capital is taka 180 million. It has credit rating grade 'BBB'. Total assets of the company stood in 2011 at TK 2841538191. Padma Islami Life Insurance Limited has a seven-member Shariah Council (Shariah Advisory Board) constituted with eminent Islamic scholars, Shariah experts and Legal experts for supervising the affairs/functions of the company in the light of Shariah.

4.6 Islami Commercial Insurance Co. Ltd.

Islami Commercial Insurance Co. Limited is also operating its services under the Islamic Shariah in Bangladesh. It has a shariah advisory board for supervising the functions of the company in the light of Shariah. 


\section{Performance analysis of Islamic insurance companies}

To evaluate the Islamic insurance companies' financial condition and performance, "check-ups" on various aspects of Islamic Insurance companies' financial health are performed. Financial ratios have been used during these check-ups. Standards of comparison consist of both the past ratios and competitors' ratios. Here researcher used time series analysis and cross-sectional analysis for evaluating the performance of five best performing Islamic insurance Companies. Financial ratios include the following ratios:

- Liquidity ratios/ Short-Term Solvency

- Leverage ratios

- Activity ratios and

- Profitability ratios.

5.1 Short-term solvency

The top three Islamic insurance companies in respect of average current ratio of last five years (Year through 2007 to 2011) are Fareast Islamic Life Insurance Co. Ltd.-average current ratio 5.618: 1, Padma Islamic Life Insurance Company Ltd. - current ratio 4.062: 1 and Prime Islamic Life Insurance Co. Ltd. current ratio 4.044: 1 . This is shown at table -1

$$
\text { Current ratio }=\frac{\text { Current Asset }}{\text { Current Liability }}
$$

Table 1: Current ratios of five Islamic insurance companies of Bangladesh

\begin{tabular}{|l|l|l|l|l|l|l|l|}
\hline Name of Companies & $\mathbf{2 0 0 7}$ & $\mathbf{2 0 0 8}$ & $\mathbf{2 0 0 9}$ & $\mathbf{2 0 1 0}$ & $\mathbf{2 0 1 1}$ & Mean & $\begin{array}{l}\text { STDE } \\
\text { V }\end{array}$ \\
\hline Fareast Islamic Life Insurance Co. Ltd. & 2.88 & 4.92 & 6.69 & 7.95 & 5.65 & 5.618 & 1.907 \\
\hline Padma Islamic Life Insurance Company Ltd. & 2.31 & 4.45 & 5.55 & 3.75 & 4.25 & 4.062 & 1.178 \\
\hline Prime Islamic Life Insurance Company Ld & 2.56 & 4.12 & 3.57 & 5.49 & 4.48 & 4.044 & 1.086 \\
\hline Takaful Islamic Insurance Ltd. & 2.77 & 3.24 & 2.74 & 2.65 & 2.45 & 2.77 & 0.291 \\
\hline Islamic Insurance Bangladesh Ltd. & 2.25 & 2.15 & 2.41 & 2.43 & 1.56 & 2.16 & 0.355 \\
\hline
\end{tabular}

On the basis of the mean current ratio of the five selected Islamic Insurance Companies ( $2.16 \leq \mu \leq 5.618)$, it can be said that short term solvency of the companies is satisfactory. All the Islamic Insurance companies appear to be reasonably liquid. The Islamic Insurance Industry will be able to avoid defaulting on its financial obligations and, thus avoid experiencing financial distress. Variations of current ratios of the Islamic Insurance companies are reasonable over the five years periods which are reflected through the standard deviation. The standard deviation (o) lies from 0.291 to 1.91 .

Quick ratio $=\frac{\text { Cash } \& \text { Equibiliant }+ \text { Short } \text { investment }+ \text { Sundrydebetors }}{\text { Sund }}$

Table 2: Quick ratios of five Islamic insurance companies of Bangladesh

\begin{tabular}{|l|l|l|l|l|l|l|l|}
\hline Name of Companies & 2007 & 2008 & 2009 & 2010 & 2011 & Mean & STDEV \\
\hline Fareast Islami Life Insurance Co.Ltd & 2.56 & 4.58 & 5.91 & 7.22 & 5.24 & 5.102 & 1.724 \\
\hline Padma Islamic Life Insurance Company Ltd. & 3.45 & 4.66 & 2.98 & 6.52 & 3.75 & 4.272 & 1.398 \\
\hline Takaful Islamic Insurance Ltd. & 2.44 & 4.88 & 4.19 & 3.84 & 5.65 & 4.2 & 1.203 \\
\hline Prime Islamic Life Insurance Co. Ltd. & 3.74 & 3.05 & 4.37 & 4.32 & 4.39 & 3.974 & 0.583 \\
\hline Islamic Insurance Bangladesh Ltd. & 2.65 & 2.45 & 3.55 & 5.12 & 3.89 & 3.532 & 1.072 \\
\hline
\end{tabular}

From the table 2, shown in the Annexure, it is found that the mean quick ratio of Fareast Islamic Life Insurance, Padma Islamic Life Insurance, Takaful Islamic Insurance, Prime Islamic Life Insurance and Islamic Insurance Bangladesh are 5.102, 4.272, 4.2, 3.974 and 3.532 respectively. It represents the satisfactory current financial condition. The trend of quick ratio of those companies is increasing that indicate the sound short term solvency of the companies, i.e., they have good ability to pay off current liabilities without relying on the sale of inventories. Standard deviations of quick ratio for the companies are $1.724,1.398,1.203,0.583$ and 1.072 respectively. It indicates that overall quality of data is satisfactory as variations are relatively lower, i.e., $0.583 \leq 0 \leq 1.724$.

Cash ratio $=\frac{\text { Cash }+ \text { Cash Equivalents }}{\text { Current Liabilities }}$ 
Table: 3- Cash ratios of five Islamic insurance companies of Bangladesh

\begin{tabular}{|llllllll|}
\hline Name of Companies & 2007 & 2008 & 2009 & 2010 & 2011 & Mean & STDEV \\
\hline Islamic Insurance Bangladesh Ltd. & 4.55 & 4.78 & 4.04 & 4.77 & 4.69 & 4.566 & 0.308 \\
\hline Prime Islamic Life Insurance Company Ltd. & 4.07 & 4.14 & 4.06 & 4.12 & 4.17 & 4.112 & 0.047 \\
\hline Takaful Islamic Insurance Ltd. & 3.56 & 3.19 & 3.59 & 3.11 & 3.78 & 3.446 & 0.284 \\
\hline Fareast Islamic Life Insurance Co.Ltd. & 3.197 & 3.263 & 3.24 & 3.29 & 3.28 & 3.254 & 0.037 \\
\hline Padma Islamic Life Insurance Company Ltd. & 2.45 & 2.85 & 2.78 & 2.66 & 2.37 & 2.622 & 0.207 \\
\hline
\end{tabular}

From the table 3, in the appendix, we find that Islamic Insurance Bangladesh Limited is in the best position among the Islamic Insurance Companies in Bangladesh according to cash ratio and its average cash ratio is 4.566.The means of Cash ratios of selected Islamic Insurance Companies are 4.566, 4.112, $3.446,3.254$ and 2.622 , i.e., $2.622 \leq \mu \leq 4.566$. Therefore the companies carry sufficient amount of cash and cash equivalents to meet the current liabilities. Their standard deviations vary from 0.037 to 0.308 over the five years periods. It reveals that the companies are maintaining good trends in short-term solvency.

Though the Islamic Insurance Companies are maintaining satisfactory level of liquidity but working capital management is not at the optimum level. The companies need to be reduced the amount of working capital.

\subsection{Financial leverage}

Financial leverage is related to the extent to which a firm relies on debt financing rather than equity. In the case of islamic insurance companies, there are no use of debt fianacing. Islamic Insurance Companies use only the equity financing under the contarcts of mudarabah, wakalah, ju'alah and waqf. Mudarabah means the giving of capital to another person who will trade with it for the purpose of sharing the profits according to a pre-agreed ratio. Wakala is a contract of agency, whereby participants remain the actual owners of the takaful fund. The principal is the participant while the agent(wakil) is the takaful operator. Under the Ju'alah contract, the participants collectively apoint the oprator to manage the takaful fund in a prescribed manner for a specified reward if done accordingly. Waqf means a unilateral contarct to relinquish a right over property and allocate it for general enjoyment of the usufruct by the specified beneficiaries. Thus debt ratios of the islamic insurance compqnies show the unpaid balances and current liabilities (non-interst bearing current obligations).

Total Debt ratio $=\frac{\text { Totalassets }- \text { TotalEquity }}{\text { Totalassets }}$

Table-4: Total Debt ratio of five Islamic Insurance companies in \%:

\begin{tabular}{lllllll}
\hline Name of Companies & $\mathbf{2 0 0 7}$ & $\mathbf{2 0 0 8}$ & $\mathbf{2 0 0 9}$ & $\mathbf{2 0 1 0}$ & $\mathbf{2 0 1 1}$ & Mean \\
\hline Prime Islamic Life Insurance Co. Ltd. & 5.32 & 5.69 & 5.12 & 5.41 & 7.66 & 5.84 \\
Fareast Islamic Life Insurance Co. Ltd. & 5.22 & 5.72 & 7.17 & 5.44 & 7.76 & 6.26 \\
Padma Islamic Life Insurance Co Ltd & 8.76 & 11.79 & 9.57 & 12.33 & 15.59 & 11.61 \\
Takaful Islamic Insurance Ltd. & 30.58 & 25.81 & 29.32 & 28.00 & 27.49 & 28.24 \\
Islamic Insurance Bangladesh Ltd. & 34.03 & 36.72 & 37.40 & 29.99 & 44.95 & 36.62 \\
\hline
\end{tabular}

From the table-4, it is found that the debt ratios ofPrime Islamic Life Insurance, Fareast Islamic Life Insurance, Padma Islamic Life Insurance, Takaful Islamic Insurance and Islamic Insurance Bangladeshare $5.84 \%, 6.26 \%, 11.61 \%, 28.24 \%$ and $36.625 \%$. It reveals that Prime Islamic Life Insurance, Fareast Islamic Life Insurance, and Padma Islamic Life Insurance companies have good ability to fulfil their obligations and to avoid insolvency and financial distress. They have also the negligible financial risk. But Takaful Islamic Insurance and Islamic Insurance Bangladesh ltd. face higher financial risk.

5.3 Asset management effeciency/activity measurement

The effectiveness of firm's asset management is measured by the asset management or activity ratios. Theses ratios also measure the ability of the firm to control its investment in assets.

Fixed asset turnover ratio $=\frac{\text { Revenue }}{\text { Net Fixed Assets }}$ 
Table 5: Fixed asset turnover ratio of five Islamic insurance companies in times

\begin{tabular}{|l|l|l|l|l|l|l|}
\hline Name of Companies & $\mathbf{2 0 0 7}$ & $\mathbf{2 0 0 8}$ & $\mathbf{2 0 0 9}$ & $\mathbf{2 0 1 0}$ & $\mathbf{2 0 1 1}$ & Mean \\
\hline Islamic Insurance Bangladesh Ltd. & .084 & .194 & .221 & .183 & .175 & 0.171 \\
\hline Padma Islamic Life Insurance Co Ltd. & .101 & .152 & .178 & .167 & .134 & 0.147 \\
\hline Prime Islamic Life Insurance Co. Ltd. & .0683 & .123 & .153 & .192 & .181 & 0.143 \\
\hline Takaful Islamic Insurance Ltd. & .094 & .075 & .144 & .162 & .198 & 0.135 \\
\hline Fareast Islamic Life Insurance Co. Ltd. & .0957 & .0804 & .0823 & .0784 & .141 & 0.096 \\
\hline
\end{tabular}

From the table-5, we find that the fixed assets turn over of the Islamic Insurance Companies are very poor $(0.096 \leq \mu \leq 0.171)$ indicating that the companies are using too many fixed assets and its poor utilization in turnig over revenues.Since Islamic Insurance Companies are new companies than the conventional in Bangladesh,conventional old firms had acquired many of their assets years ago at low prices with the islamic companies that had acquired their fixed assets only recently, that is why the islamic companies have the lower fixed assets turn over ratios.

Receivables Turnover $=\frac{\text { Revenue }}{\text { SundryDebtors }}$

Table-6: Receivables Turnover of five Islamic insurance companies

\begin{tabular}{|l|l|l|l|l|l|l|}
\hline Name of Companies & $\mathbf{2 0 0 7}$ & $\mathbf{2 0 0 8}$ & $\mathbf{2 0 0 9}$ & $\mathbf{2 0 1 0}$ & $\mathbf{2 0 1 1}$ & Mean \\
\hline Prime Islamic Life Insurance Co. Ltd. & .98 & 1.89 & 2.78 & 1.73 & .84 & 1.644 \\
\hline Fareast Islamic Life Insurance Co. Ltd. & 1.38 & 2.14 & .94 & 1.76 & 1.15 & 1.474 \\
\hline Padma Islamic Life Insurance Co. Ltd. & 1.44 & 1.84 & .88 & 1.74 & .964 & 1.3728 \\
\hline Islamic Insurance Bangladesh Ltd. & 1.28 & 2.38 & .498 & .977 & 1.26 & 1.279 \\
\hline Takaful Islamic Insurance Ltd. & .72 & .66 & .62 & .58 & .98 & 0.712 \\
\hline
\end{tabular}

From the table-6, it is found that the average receivable turn over ratios of Prime Islamic Life Insurance, Fareast Islamic Life Insurance, Padma Islamic Life Insurance, Islamic Insurance Bangladesh and Takaful Islamic Insurance are1.644, 1.474, 1.373, 1.279 and 0.712 respectively. The poor average receivable turn over ratios indicate that the companies extend relatively more credits to their customers. Hence, it also reveals their less efficiency in managing credits. The Islamic insurance companies should reduce the laxity in managing receivables.

5.4 Management's operating efficiency and effectiveness

Management's operating efficiency and effectiveness are measured by the profitability ratios. Profitability ratios measure the income or operating successs of an enterprise for a given period of time. A company should earn income to survive and grow over a long period of time. Income is essential, but it is not allowed by Shariah to assume that every action initiated by management of a company should be aimed at maximizing profits, irrespective of social and moral consequences. It is unfortunate that the word 'profit' is looked upon as a term of abuse since some conventional firms always want to maximize profits at the cost of employees, customers and society. Except such infrequent cases, it is a fact that sufficient income must be earned to sustain and survive the operations of the business to be able to obtain funds from investors for expansion and growth and to contribute towards the social overheads for the welfare of the society (Drucker, 1968). Since the age of Islamic Insurance Companies are less than the conventionals in Bangladesh, they face large start-up costs in a few yearsas a consequence, produce low initial profits. Thus current profits are the relative lower reflection of true more future prifitability. Here, stanadard deviation (o) and co-efficient of variation (C.V.) are calculated with the ratios to measure the total risk and per unit of risk of the companies respectively. Profit Margin $=\frac{\text { NetIncome }}{\text { Revenue }}$

Table: 7-Profit margin ratios of five Islamic insurance companies of Bangladesh in \%

\begin{tabular}{|l|l|l|l|l|l|l|l|l|}
\hline Name of Companies & $\mathbf{2 0 0 7}$ & $\mathbf{2 0 0 8}$ & $\mathbf{2 0 0 9}$ & $\mathbf{2 0 1 0}$ & $\mathbf{2 0 1 1}$ & Mean & $\begin{array}{l}\text { STDEV } \\
\text { \% }\end{array}$ & $\begin{array}{l}\text { C.V. } \\
\text { (times) }\end{array}$ \\
\hline $\begin{array}{l}\text { Padma Islamic Life Insurance Co } \\
\text { Ltd. }\end{array}$ & 37.40 & 25.61 & 19.84 & 38.52 & 38.10 & 31.894 & 8.624 & 0.270 \\
\hline $\begin{array}{l}\text { Fareast Islamic Life Insurance } \\
\text { Co.Ltd. }\end{array}$ & 21.14 & 23.75 & 25.41 & 32.85 & 28.35 & 26.30 & 4.501 & 0.171 \\
\hline Takaful Islamic Insurance Ltd. & 18.10 & 20.56 & 24.81 & 31.84 & 27.52 & 24.566 & 5.467 & 0.223 \\
\hline Prime Islamic Life Insurance Co. & 18.47 & 21.48 & 17.51 & 28.95 & 32.14 & 23.71 & 6.508 & 0.274 \\
\hline
\end{tabular}




\begin{tabular}{|l|l|l|l|l|l|l|l|l|}
\hline Ltd & & & & & & & & \\
\hline Islamic Insurance Bangladesh Ltd. & 20.61 & 13.52 & 30.41 & 25.41 & 26.41 & 23.272 & 6.472 & 0.278 \\
\hline
\end{tabular}

From the table-7 of Appendix, we found that the average profit margins ( $\mu$ ) of Padma Islamic Life Insurance, Fareast Islamic Life Insurance, Takaful Islamic Insurance, Prime Islamic Life Insurance and Islamic Insurance Bangladesh are 31.894\%, 26.30\%, 24.566\%, 23.71\%, and 23.272\%respectively. Padma Islamic life Insurance Company experienced a decrease in its profit margin from 2007 to 2008, 2008 to 2009 and an increase from 2009 to 2010 and again somewhat decrease from 2010 to 2011. Its average profit margin is high in comparison with the Islamic Insurance Industry average in Bangladesh. Its standard deviation (o) is also high than industry average. Therefore, on the basis of co-efficient of variation (C.V.) of profit margin, it can be said that Fareast Islamic Life Insurance is the best performing company because of having lowest risk $(\mathrm{C} . \mathrm{V} .=0.171)$ in the industry. The table- 4 also shows that per unit risks of the company for profit margin lies between 0.171 and 0.27 , i.e., $0.171 \leq \mathrm{C} . \mathrm{V} \leq 0.27$. These low riskiness of the companies represent good trends in profit margin that indicate the companies' ability to provide service at a low cost. Average profit margins of the Islamic Insurance Companies $(23.272 \% \leq \mu \leq 31.894 \%)$ represent the efficient management of the companies in investing, administering and selling the products. It also indicates the firms' capacity to withstand adverse economic conditions. They are in an advantageous position to survive in the face of global economic crisis and national political and economic adverse situation.

The Return on Assets (ROA) $=\frac{\text { Net Income }}{\text { Total Assets }}$

Table 8: Return on Assets of five Islamic insurance companies of Bangladesh

\begin{tabular}{|l|l|l|l|l|l|l|l|l|}
\hline Name of Companies & $\begin{array}{l}\mathbf{2 0 0 7} \\
(\boldsymbol{\%})\end{array}$ & $\begin{array}{c}\mathbf{2 0 0 8} \\
(\boldsymbol{\%})\end{array}$ & $\begin{array}{l}\mathbf{2 0 0 9} \\
(\boldsymbol{\%})\end{array}$ & $\begin{array}{l}\mathbf{2 0 1 0} \\
(\boldsymbol{\%})\end{array}$ & $\begin{array}{l}\mathbf{2 0 1 1} \\
(\boldsymbol{\%})\end{array}$ & $\begin{array}{l}\text { Mean } \\
(\boldsymbol{\%})\end{array}$ & $\begin{array}{l}\text { STDEV } \\
(\boldsymbol{\%})\end{array}$ & C.V. \\
\hline Padma Islamic Life Insurance Co Ltd & 14.20 & 15.14 & 18.74 & 16.12 & 15.48 & 15.936 & 1.714 & 0.108 \\
\hline Prime Islamic Life Insurance Co. Ltd. & 13.20 & 14.45 & 17.51 & 16.21 & 13.20 & 14.914 & 1.905 & 0.128 \\
\hline Takaful Islamic Insurance Ltd. & 13.78 & 14.87 & 15.47 & 14.98 & 13.82 & 14.584 & 0.751 & 0.051 \\
\hline Fareast Islami Life Insurance Co.Ltd & 14.50 & 13.85 & 12.96 & 16.32 & 14.50 & 14.426 & 1.233 & 0.085 \\
\hline Islamic Insurance Bangladesh Ltd. & 12.40 & 13.45 & 14.78 & 13.56 & 15.68 & 13.974 & 1.273 & 0.091 \\
\hline
\end{tabular}

From the table- 8 of the appendix, we found that that the average return on total assets (ROA) of Padma Islamic Life Insurance, Prime Islamic Life Insurance, Takaful Islamic Insurance, Fareast Islamic Life Insurance, , and Islamic Insurance Bangladesh are 15.94\%, 14.91\%, 14.58\%, 14.43\%, and $13.97 \%$ respectively. Trends of ROA of the Islamic Insurance Companies are resonably positive upward shown in the table-5. Their standard deviations $(0.751 \% \leq 0 \leq 1.905 \%)$ indicate that the fluctuations of the ROA are in the tolerance limit over the five years periods. Takaful Islamic insurance company's per unit risk is lowest among the Islamic insurance companies in Bangladesh. Its coefficient of variation is 0.51 and the coefficient of variation of Padma Life Insurance Company is 0.108. Though Padma Islamic Life Insurance Company has the highest average ROA but on the basis of risk-return relationship Takaful Islamic insurance company is in the good position.

The average returns on common equity of Padma Islamic Life Insurance, Fareast Islamic Life Insurance, Prime Islamic Life Insurance, Islamic Insurance Bangladesh and Takaful Islamic Insurance are 39.98\%, $39.94 \%, 33.68 \%, 32.72 \%$ and $31.51 \%$ respectively shown in the table-9.

$$
\mathrm{ROE}=\frac{\text { Net Income }}{\text { Avg.shareholder's Equity }}
$$

Table 9: Return on Equity of five Islamic insurance companies

\begin{tabular}{|l|l|l|l|l|l|l|l|l|}
\hline Name of Companies & $\mathbf{2 0 0 7}$ & $\mathbf{2 0 0 8}$ & $\mathbf{2 0 0 9}$ & $\mathbf{2 0 1 0}$ & $\mathbf{2 0 1 1}$ & Mean & STDE & C.V. \\
\hline $\begin{array}{l}\text { Padma Islamic Life Insurance Com } \\
\text { Ltd. }\end{array}$ & 41.17 & 39.14 & 38.46 & 40.12 & 41.02 & 39.98 & 1.18 & 0.03 \\
\hline Fareast Islamic Life Insurance Co.Ltd & 40.37 & 38.09 & 41.67 & 38.21 & 41.38 & 39.94 & 1.71 & 0.04 \\
\hline Prime Islamic Life Insurance Co. Ltd. & 29.78 & 29.34 & 33.89 & 37.82 & 37.56 & 33.68 & 4.07 & 0.12 \\
\hline Islamic Insurance Bangladesh Ltd. & 32.84 & 29.47 & 31.45 & 35.12 & 34.74 & 32.72 & 2.35 & 0.07 \\
\hline Takaful Islamic Insurance Ltd. & 28.45 & 29.54 & 31.78 & 33.78 & 33.98 & 31.51 & 2.48 & 0.08 \\
\hline
\end{tabular}

The ROE of the companies are much more than the ROA. Lower fluctuations revealed by the standard deviations $(1.18 \% \leq 0 \leq 4.07 \%)$ in the ROE of the companies over the periods indicate the stable ROE. It is 
found that the Padma Islamic Life Insurance Company has the highest average ROE $(\mu=39.98 \%)$ and the lowest per unit risk (C.V. $=0.03)$ among the Islamic insurance companies in Bangladesh. The good returns on equity of the companies $(31.51 \% \leq \mu \leq 39.98 \%)$ indicate that the owners' resource management of the companies are both efficient and effective. It also reveals the relative good performance and strength of the companies in attracting future investments. Since ROE does not consider the amount of invested capital, it needs to be analysed the size of the investments with the return on equity to determine its effect on shareholder value.

5.5 Growth analysis

The researcher has calculated growth rate in total assets, balance of fund, liability and provision, sundry creditors, sundry debtors, premium deposits, fixed assets, management expenses, net profit, cash and bank balance for the growth analysis.

Table: 10-Growth rate in Balance of Fund

\begin{tabular}{llllll}
\hline Name of Companies & $\mathbf{2 0 0 8}(\%)$ & $\mathbf{2 0 0 9}(\%)$ & $\mathbf{2 0 1 0}(\%)$ & $\mathbf{2 0 1 1}(\%)$ & Mean(\%) \\
\hline Prime Islamic Life Insurance Co. Ltd & 63.68 & 62.62 & 49.61 & 31.00 & 51.73 \\
Fareast Islamic Life Insurance Co. Ltd. & 21.84 & 14.74 & -8.93 & 54.12 & 20.44 \\
Padma Islamic Life Insurance Company Ltd & 11.79 & -1.09 & 41.83 & 7.65 & 15.05 \\
Islamic Insurance Bangladesh Ltd. & 11.75 & -13.48 & 50.61 & 1.68 & 12.64 \\
Takaful Islamic Insurance Ltd. & 9.59 & -8.73 & 24.71 & 12.75 & 9.58 \\
\hline
\end{tabular}

Table-10 shows the growth rate in balance of fund. Prime Islamic Life Insurance Company also has the highest growth (average growth rate 51.73\%) in balance of fund. Padma Islamic Life Insurance, Islamic Insurance Bangladesh andTakaful Islamic Insurance Company faced negative growth in balance of fund during the year 2009 and Fareast Islamic Life Insurance faced negative growth in 2010. Takaful Islamic Insurance Company has the lowest average growth in balance of fund. The average growth rate in cash and bank balance of Prime Islamic Life Insurance,Fareast Islamic Life Insurance, Takaful Islamic Insurance, Islamic Insurance Bangladeshand Padma Islamic Life Insurance are $31.17 \%, 28.92 \%, 24.16 \%, 22.35 \%$ and $19.11 \%$ which is shown in the table-11.

Table: 11-Growth rate of Cash and Bank Balance

\begin{tabular}{llllll}
\hline ame of Companies & $\mathbf{2 0 0 8}$ & $\mathbf{2 0 0 9}$ & $\mathbf{2 0 1 0}$ & $\mathbf{2 0 1 1}$ & Mean \\
\hline Prime Islamic Life Insurance Co. Ltd & 33.38 & 72.87 & 1.33 & 17.08 & 31.17 \\
Fareast Islamic Life Insurance Co. Ltd. & 42.87 & 24.10 & -4.59 & 19.78 & 28.92 \\
Takaful Islamic Insurance Ltd. & 59.88 & 2.72 & 14.38 & 19.66 & 24.16 \\
Islamic Insurance Bangladesh Ltd. & 33.69 & 68.23 & -8.2 & -4.32 & 22.35 \\
Padma Islamic Life Insurance Company Ltd & 39.18 & 8.86 & 26.92 & 1.49 & 19.11 \\
\hline
\end{tabular}

Growth rate in sundry creditors and debtors are shown in the table -12 and table-13 respectively.

Table: 12-Growth rate of Sundry Creditors

\begin{tabular}{llllll}
\hline Name of Companies & $\mathbf{2 0 0 8}$ & $\mathbf{2 0 0 9}$ & $\mathbf{2 0 1 0}$ & $\mathbf{2 0 1 1}$ & Mean \\
\hline Islamic Insurance Bangladesh Ltd. & 177.67 & 217.47 & -54.83 & 28.16 & 92.12 \\
Prime Islamic Life Insurance Co. Ltd & 49.42 & 28.04 & 100.77 & 54.17 & 58.10 \\
Padma Islamic Life Insurance Company Ltd & 38.53 & 8.42 & 16.96 & 28.10 & 23.00 \\
Fareast Islamic Life Insurance Co. Ltd. & 28.17 & -13.27 & 37.42 & 19.84 & 18.04 \\
Takaful Islamic Insurance Ltd. & 45.82 & -77.21 & 7.76 & 28.13 & 1.125 \\
Prime Islamic Life Insurance Co. Ltd & 19.82 & -53.99 & -4.84 & 4.18 & -8.71 \\
\hline
\end{tabular}


Table: 13-Growth rate of Sundry Debtors

\begin{tabular}{llllll}
\hline Name of Companies & $\mathbf{2 0 0 8}$ & $\mathbf{2 0 0 9}$ & $\mathbf{2 0 1 0}$ & $\mathbf{2 0 1 1}$ & Mean \\
\hline Islamic Insurance Bangladesh Ltd. & 184.48 & 102.54 & 37.41 & 3.03 & 81.87 \\
Fareast Islamic Life Insurance Co. Ltd. & 94.14 & -25.83 & 70.46 & 34.82 & 43.40 \\
Takaful Islamic Insurance Ltd. & 34.39 & 46.44 & 16.17 & 29.87 & 31.72 \\
Padma Islamic Life Insurance Company Ltd & 17.59 & 55.89 & 33.33 & -42.87 & 15.99 \\
Prime Islamic Life Insurance Co. Ltd & 118.93 & -95.70 & -38.79 & 48.14 & 8.14 \\
\hline
\end{tabular}

Islamic Insurance Bangladesh Limited's average growth rate of sundry creditors is highest and its average growth rate is $92.12 \%$. The company has also the highest average growth rate of Sundry Debtors of $81.87 \%$. Prime Islamic Life Insurance Company Limited's average growth rate in sundry debtors is lowest and it is $8.14 \%$. The growth rate of premium deposit is shown in the table-14.

Table: 14-Growth rate of Premium Deposits

\begin{tabular}{llllll}
\hline ame of Companies & $\mathbf{2 0 0 8}(\%)$ & $\mathbf{2 0 0 9}(\boldsymbol{\%})$ & $\mathbf{2 0 1 0}(\boldsymbol{\%})$ & $\mathbf{2 0 1 1}(\boldsymbol{\%})$ & Mean(\%) \\
\hline Fareast Islamic Life Insurance Co. Ltd. & -12.10 & 17.41 & 36.82 & 19.57 & 15.43 \\
Takaful Islamic Insurance Ltd. & 1.15 & -1.18 & 31.93 & 20.21 & 13.03 \\
Padma Islamic Life Insurance Company Ltd & -4.08 & 18.24 & 3.89 & 27.23 & 11.32 \\
Islamic Insurance Bangladesh Ltd. & 8.92 & -1.66 & 3.73 & -3.897 & 1.77 \\
\hline
\end{tabular}

It reveals that there is the highest average growth rate in premium deposits of Fareast Islamic Life Insurance Company (15.43\%). Prime Islamic Life insurance Co. limited has the negative average growth rate in premium deposits of $-8.71 \%$ for the selected four years periods. Fareast and Padma Islamic Life Insurance Co. Itd. experienced negative growth rate in premium deposits in the year 2008. There is slow growth in premium deposits of Islamic Insurance Industry. The increasing trend of Growth rate in fixed assets of Islamic Insurance Industry in Bangladesh indicates the expanding business scenario which is shown in table-15.

Table: 15-Growth rate of Fixed Assets

\begin{tabular}{llllll}
\hline ame of Companies & $\mathbf{2 0 0 8}(\boldsymbol{\%})$ & $\mathbf{2 0 0 9 ( \% )}$ & $\mathbf{2 0 1 0}(\boldsymbol{\%})$ & $\mathbf{2 0 1 1}(\boldsymbol{\%})$ & Mean (\%) \\
\hline Prime Islamic Life Insurance Co. Ltd & 13.28 & 58.08 & 44.18 & 57.44 & 43.25 \\
Fareast Islamic Life Insurance Co. Ltd. & 21.87 & -8.29 & 36.84 & 43.15 & 23.39 \\
Takaful Islamic Insurance Ltd. & 3.28 & -4.29 & 83.25 & 4.27 & 21.63 \\
Padma Islamic Life Insurance Company Ltd & 5.996 & 19.89 & 43.49 & 9.61 & 19.75 \\
Islamic Insurance Bangladesh Ltd. & 3.19 & 5.72 & 1.001 & 18.25 & 7.04 \\
\hline Table: 16-Growth rate of total assets & & & & & \\
\hline Name of Companies & 2008 & 2009 & $\mathbf{2 0 1 0}$ & $\mathbf{2 0 1 1}$ & Mean \\
\hline Prime Islamic Life Insurance Co. Ltd & 60.73 & 59.66 & 49.34 & 32.78 & 50.63 \\
Padma Islamic Life Insurance Company Ltd & 59.22 & 29.33 & 44.72 & 19.22 & 38.12 \\
Islamic Insurance Bangladesh Ltd. & 58.38 & 56.29 & 12.67 & 20.61 & 36.99 \\
Takaful Islamic Insurance Ltd. & 25.28 & 10.36 & 23.20 & 59.33 & 29.54 \\
Fareast Islamic Life Insurance Co. Ltd. & 31.44 & 21.25 & 24.15 & 29.87 & 26.68 \\
\hline
\end{tabular}

From the table-16, it is found that thegrowth rate in total assets of Prime Islamic Life Insurance for four years $(2008-2011)$ are $60.73 \%, 59.66 \%, 49.34 \%$, and $32.78 \%$ and its average growth rate is $50.63 \%$. The growth rate in total assets of Padma Islamic Life Insurance for four years are 59.22\%, 29.33\%, 44.72\%, and 
$19.22 \%$ and its average growth rate is $38.12 \%$. The growth rate in total assets of Islamic Insurance Bangladesh limited for four years are 58.38\%, 56.29\%, 12.67\%, 20.61\%, and its average growth rate is $36.99 \%$. The growth rate in total assets of Takaful Islamic Insurance limited for four years are $25.28 \%$, $10.36 \%, 23.20 \%, 59.33 \%$, and its average growth rate is $29.54 \%$. The growth rate in total assets of Fareast Islamic Life Insurance limited for four years are $31.44 \%, \quad 21.25 \%, 24.15 \%, 29.87 \%$, and its average growth rate is $26.68 \%$. From the study, it can be concluded that the Prime Islamic Life Insurance Company has the highest growth (average growth rate 50.63\%) in total assets and Fareast Islamic Life Insurance Limited has the lowest average growth rate $(26.68 \%)$ in total assets for the last for years. The high growth rate in assets reveals that thetrend in investment of Islamic Insurance Companies is increasing and they can attract the new investors. The growth rates in liability and provision are shown in the table 17.

Table: 17-Growth rate of Liability and Provision

\begin{tabular}{llllll}
\hline Name of Companies & $\mathbf{2 0 0 8}$ & $\mathbf{2 0 0 9}$ & $\mathbf{2 0 1 0}$ & $\mathbf{2 0 1 1}$ & Mean \\
\hline Padma Islamic Life Insurance Company Ltd & 29.79 & 46.37 & 86.52 & 50.75 & 53.36 \\
Islamic Insurance Bangladesh Ltd. & 24.12 & 17.07 & 18.59 & 63.90 & 30.92 \\
Prime Islamic Life Insurance Co. Ltd & 15.94 & 17.41 & 23.8 & 16.37 & 18.38 \\
Fareast Islamic Life Insurance Co. Ltd. & 18.41 & -13.54 & 11.79 & 54.28 & 17.74 \\
Takaful Islamic Insurance Ltd. & -20.23 & 25.36 & 17.63 & -9.79 & 3.24 \\
\hline
\end{tabular}

It is found that the Padma Islamic Life Insurance has the highest average growth in liability and provision of 53.36\% and its trend in growth is positive. Takaful Islamic Insurance Ltd. Company experienced negative growth in liability and provision in 2008 and in 2011. Fareast Islamic Life Insurance faced negative growth in 2009. The mean growth rate in management expenses of Prime Islamic Life Insurance, Fareast Islamic Life Insurance, Padma Islamic Life Insurance, Takaful Islamic Insurance and Islamic Insurance Bangladesh are22.35\%, 12.84\%, $12.56 \%, 10.55 \%$ and $8.88 \%$ respectively which are shown in table-18.

Table: 18-Growth rate of Management Expenses

\begin{tabular}{llllcc}
\hline ame of Companies & $\mathbf{2 0 0 8}(\boldsymbol{\%})$ & $\mathbf{2 0 0 9}(\boldsymbol{\%})$ & $\mathbf{2 0 1 0}(\boldsymbol{\%})$ & $\mathbf{2 0 1 1}(\boldsymbol{\%})$ & $\mathbf{M e a n}(\boldsymbol{\%})$ \\
\hline Prime Islamic Life Insurance Co. Ltd & 20.54 & 26.24 & 18.19 & 24.42 & 22.35 \\
Fareast Islamic Life Insurance Co. Ltd. & 17.59 & -8.13 & 22.48 & 19.41 & 12.84 \\
Padma Islamic Life Insurance Company Ltd & 7.05 & 10.28 & 22.44 & 10.48 & 12.56 \\
Takaful Islamic Insurance Ltd. & 8.09 & 12.65 & 8.03 & 13.44 & 10.55 \\
Islamic Insurance Bangladesh Ltd. & 13.54 & 2.29 & 22.43 & -2.73 & 8.88 \\
\hline
\end{tabular}

Fareast Islamic Life Insurance and Islamic Insurance Bangladesh experienced negative growth in management expenses in 2009 and in 2011. The average growth rate in net profit of Prime Islamic Life Insurance, Fareast Islamic Life Insurance, Takaful Islamic Insurance, Padma Islamic Life Insurance, and Islamic Insurance Bangladesh are51.75\%, 51.22\%, 32.16\%, 23.97\% and $22.78 \%$ respectively which is shown in table -19.

\section{Table: 19-Growth rate of Net Profit:-}

\begin{tabular}{llllll}
\hline ame of Companies & $\mathbf{2 0 0 8}(\%)$ & $\mathbf{2 0 0 9}(\%)$ & $\mathbf{2 0 1 0}(\%)$ & $\mathbf{2 0 1 1}(\%)$ & Mean $(\%)$ \\
\hline Prime Islamic Life Insurance Co. Ltd & 63.68 & 62.66 & 49.63 & 31.01 & 51.75 \\
Fareast Islamic Life Insurance Co. Ltd. & 59.74 & 68.42 & 47.25 & 29.48 & 51.22 \\
Takaful Islamic Insurance Ltd. & -1.85 & 16.48 & 65.78 & 48.22 & 32.16 \\
Padma Islamic Life Insurance Company Ltd & 16.14 & 30.23 & 41.82 & 7.68 & 23.97 \\
Islamic Insurance Bangladesh Ltd. & 3.21 & -4.55 & 124.43 & -31.98 & 22.78 \\
\hline
\end{tabular}

These positive average growth rates in net profit reveal the increasing performance of the Islamic Insurance industry. 


\section{Benefits of practicing Islamic insurance in Bangladesh \\ Product coverage}

Since Islam emphasizes distributive justice and incorporates in its system a program for organized community with the commitment of human welfare, there ought to be compulsory arrangement for insurance against unemployment and occupational hazards, old age pension, and survivors' benefit. The Islamic Society should also provide assistance to those who, because of disability, physical or mental handicaps or obsolescence, are unable to support themselves or to attain a respectable standard of living by their own effort. The Takaful Act of Malaysia 1984 defines takaful as "a scheme based on brotherhood, solidarity, and mutual assistance which provide for mutual financial aid and assistance to the participants in case of need whereby the participant mutually agree to contribute for that purpose. "There are two types of takaful schemes are available in the Islamic Insurance Companies: i) General takaful scheme and ii) Family takaful (Life insurance). The Takaful Islamic Insurance Company insures all traditional lines of non-life insurance businesses viz. - Fire \& allied risks including flood, cyclone, earthquake, Typhoon, malicious damage, burglary, riot, strike, damage, house breaking, industrial all risks, DOS, machinery break-down, loss of profit, business interruption, CAR/EAR, personal accident including workmen compensation, motor insurance of all descriptions \& value, Travel medical \& medical insurance including treatment abroad to name a few broad lines. Meghna Life Insurance Company Ltd. has introduced two categories of takaful products with its other conventional products. The two takaful categories of policies are Islami Bima and Islami Khudra Bima. Islami Bima was introduced to turn Life Insurance into a profitable savings arrangement through payment by installments on the basis of Islami Shariah and transparent and impeccable servicing. The Plans of Islami Bima are Islamic Endowment Insurance Plan (Takaful) - with Profit, Islami Takaful 3 (three) Payment Insurance Plan - with Profits, Islami Bima (Takaful) Biennial Endowment Insurance Plan - with Profits, Islami Bima (Takaful) Child Protection Endowment Insurance Plan - with Profits, Islami Bima (Takaful) Insurance-Cum Pension Plan - without Profits, Islami Bima (Takaful) Single Premium Guaranteed Benefit Plan - without Profit, Islami Bima (Takaful) Education Expense Insurance Plan - with Profits, Islami Bima (Takaful) Premium Back Term Insurance - without Profits, Islamic Endowment Plan (Takaful) - with Profits, Islamic Biennial Payment Assurance (Takaful) Plan - with Profits, Islami 5 (five) Instalment Insurance Plan - with Profits and Takaful Islami DPI - with Profits. The object of Islami Khudra Bima (Takaful) is to create habit of savings for the low income group of people of Bangladesh, ensure profit and savings through modern insurance facilities and to introduce interest free Islami Bima. The plans of Islami Khudra Bima are Endowment Insurance - with Profits, Child Protection Endowment Insurance - with Profits, Single Premium Guaranteed Insurance - with Profits and Islami Khudra DPS - with Profits. The types of General Takaful Business being transacted by the Islamic Insurance Bangladesh Limited Company are Fire Takaful (Basic Fire, Fire and allied perils, Householders, Industrial all risks, Business interruption), Marine Takaful (Marine Cargo, Marine Hull, Marine Freight), Motor Takaful (Private Vehicle, Commercial Vehicle, Motor Cycle), Engineering Takaful (Contractor's All Risks, Machinery Breakdown, Deterioration of Stock, Loss of Profit, Erection All Risks), Miscellaneous Takaful (Personal Accident, Group Personal Accident, Employer's Liability, Workmen's Compensation, Burglary, Public Liability, Fidelity Guarantee, Computer (Material damage), Cash in Transit, Cash on Counter, Cash in Safe). The products of Prime Islami life Insurance are Islamic Endowment Assurance Plan (Hajj Bima) with profit, Three payment Endowment Assurance plan-with profit, Prime Islami deposit Pension Scheme, Five payment Endowment Assurance plan -without profit \& Loss Basis, Multiple Benefits Life Assurance Plan (without profit), Couple Assurance Plan (Den Mohar Bima) with profit, Child Protection Assurance Plan- with profit, Kalyan Bima - Two Payment Deposit Pension Scheme - With Profit, Gift Assurance plan (Upahar Bima)-with profit, Biennial Payment Assurance Plan-with profit, Amar Priya Bima -with profit, Multi single Premium Multi pay Plan, Single Premium savings policy- without profit, Double payment Single Premium savings policy-without profit, Assurance Cum pension and Medical Benefit-Without profit, Premium back term assurance plan, Group Term Assurance plan, Endowment Assurance Plans - without profit, Premium Back Group assurance Plan, and Karmajibi Kalyan Bima - (Group term Insurance). The products of Padma Islami Life Insurance Limited are Convertible Endowment Assurance (With Profits), Endowment Assurance Plan (With Profits), Anticipated Endowment Assurance Plan-3 stage (With Profits), Anticipated Endowment Assurance Plan-4 stage (With Profits), Child Protection Assurance (With Profits), Pension Assurance (With Profits), Hajj/Omrah Assurance- Takaful (With Profits),Marriage/Moharana Assurance- Takaful (With Profits), Biennial Assurance- Takaful (With Profits), Single Premium Endowment Assurance (With Profits), Anticipated Endowment Assurance-5 Stage (With Profits), Deposit Pension Scheme -(With Profits), and 
Premium Refund Term Assurance (With Profits).The respondents' (randomly selected 40 clients) behaviors towards the various types of General Takaful scheme are shown as follows:

a) Fire Takaful scheme- $33 \%$ of sample respondents have invested in the fire takaful policies.

b) Motor Takaful Scheme - 26\% of sample respondents have taken motor insurance policies.

c) Accident/miscellaneous Takaful scheme-11\% of sample respondents have taken miscellaneous insurance policies.

d) Marine Takaful scheme- 20\% of sample respondents have taken marine policies. e) Engineering Takaful scheme- 10\% of sample respondents have taken engineering takaful scheme.

The study has identified some benefits or reasons of practicing Islamic insurance in Bangladesh by conducting interview of 40 clients of the Islamic insurance companies.

Mobilization of savings

Islamic Insurance companies are serving as the complimentary institutions of Islamic banks. It enhances more substitutes to the Muslims to make savings in a safe and more organized manner. Takaful companies mobilize the savings in a profitable manner using as the investment savings under the wakalah, mudarabah, ju'alah and waqf modes. Thus Takaful companies play the role as savings institutions and custodian of money deposited in its custody to serve the future interest of the Muslim community (Ummah). $25 \%$ of sample respondents have taken Islamic insurance for mobilizing their funds.

Islamically approved (halal) investment opportunity

Islamic Insurance companies put emphasis on saving and productive use of savings. Thus the takaful companies assemble the small deposits and savings of individuals into a common pool and make these deposits available for large investment opportunities, ensuring the productive use of society's savings in the islamically approved (halal) areas. Therefore, by joining a Takaful policy, the policy holder gains the added benefit of a golden opportunity to invest the money in accordance with Islamic principles.55\% of sample respondents have taken Islamic insurance for having halal investment opportunity.

Opportunity to perform good deeds and to do charitable works

Takaful operators do good deeds and charitable works in order to maintain a good corporate reputation which adds to the reputational capital. They are very committed to perform good deeds and to do charitable works such as giving scholarships, activities related to environmental issues, giving cash contribution, building homes for the underprivileged, establishing schools and college for the orphans and building canteens and hostels for the community. By joining takaful plan, one is indirectly involved in charity and welfare. So, by participating in a Takaful Scheme, the contribution money (premium) is donated to the Special fund and will be used for any claims by other fellow participants (or the dependents) who are suffering from loss or misfortune. So, this portion of the money does not belong to the policyholder, as upon entering into the Takaful contract, he/she has already promised to donate it to this Special fund. In this way, policy holders are participating in the corporate social responsibilities (CSR) activities. $15 \%$ of sample respondents have taken Islamic insurance for having opportunity to do good deeds and charitable works.

Full return in the case of withdrawing policy

5\%of sample respondents have taken Islamic insurance for having opportunity to get back full amount invested if they are not willing to continue premium.

Zakat

Takaful is a socio-economic device which implies sharing of losses sustained by some members of a group by all the members of that group. It provides economic security against loss of life or property. Islamic insurance also provides indemnity to persons for legal liability. Therefore it resembles the concept of 'Baitul-Maal'. In Islamic based insurance, the company pays the Zakat of the insured's paid premiums as well as on the profit made by the company. The company pays the Zakat on its own liable income. The Zakat paid on behalf of the insured is deducted from his account. In principle, the amount of Zakat of all the insured is accumulated and used in a more collective and constructive way. This serves the purpose of "Baitul Maal". Takaful accumulates the Zakat into a large sum and uses collectively to help to a large number of people. $80 \%$ of sample respondents are of the opinion that the company pays Zakat on their investment, $10 \%$ of sample respondents are of the opinion that the company pays government tax only and $10 \%$ of sample respondents are of the opinion that the company pays both zakat and government tax and there is nobody of the opinion for not knowing about the company's payment.

Special issues and challenges facing by the takaful industry

Through the literature review the researcher has identified the issues and challenges facing by the takaful industry. And then an opinion survey performed among the 40 respondents from the takaful personnel and 
40 respondents from the clients of takaful industry to find out the issues and challenges facing by the takaful industry in Bangladesh. Mr.Chakib Abouzaid (2007) identified six challenges of takaful industry as lack of statistics and information, lack of legal framework, lack of market research and R\&D, lack of expertise and standardisation, limited investment opportunities and heavy reliance on conventional reinsurance. The major challenges faced by the takaful industry are raising customer awareness and education, expanding product innovation, creative product design and marketing, offering attractive investment choices and finding a AAA rated international reinsurance companies willing to accept a re-takaful (Dirrheimer \& Jaffer, 2006). There are some challenges and issues in takaful statistics and takaful sector monitoring. These are very small size of local human capital, lack of co-ordination on issues of gathering information for the purpose of analysing and disseminating, lack of support at the regulatory level with not much pro-active action and lack of disclosure of sufficient financial information (Ajmal Bhatty, 2010). Takaful products reveal themselves in emerging markets, and as such, they face challenges such as immature infrastructure for both operations and communications insurance activities (Swartz and Coetzer, 2010). As takaful originates from an Islamic concept, one of the greatest challenges facing the takaful industry is the misconception that it is exclusively for Muslims (Divanna, 2009). Lack of society's awareness regarding the importance of insurance is one of the greatest challenges to the development and growth of the national and global industry (Ahmad, 2007).Lim, Idris and Carissa (2010) identified four challenges for the takaful industry as absence of micro takaful to provide for the needs of the rural market, lack of knowledgeable and qualified people in the industry, lack of efficient takaful operators for re-takaful industry and shortage of innovative products specially attracting the non-Muslim customers. Challenges of the re-takaful industry are limited capacity, competition, lack of rating, lack of expertise and lack of transparency in reports (ISRA,2011). Form analysis of the above literature, we can discuss the issues and challenges in the following way:

a. Key Issues and Challenges

b. Technical Issues and Challenges

a. Key issues and challenges

Some of the key issues and challenges facing the Takaful industry are:

i. $\quad$ Scarcity of human resources with both insurance and Shariah expertise

ii. Lack of standardization in the industry that is due to Shariah interpretations

iii. Diverging regulatory approaches and the lack of centralized regulations

iv. Shortage of suitable assets

These are discussed in further detail below:

i. Scarcity of human resources with both insurance and Shariah expertise

One of the major challenges faced by the Islamic Insurance Companies in Bangladesh is the lack of knowledgeable and qualified personnel. Most of the companies typically employ human resources with conventional insurance experiences. These resources typically tend to adapt their previous experiences to incorporate Shariah compliance rules in their new role that hamper the smooth takaful operations. 75\% respondents have argued there is the scarcity of qualified personnel in Takaful industry in Bangladesh.

\section{ii. Lack of standardization in the industry that is due to Shariah interpretations}

Despite the takaful industry expanding rapidly, there are still some issues currently being debated among shariah scholars and muslim jurists. For example, the inconsistency of shariah interpretations can be seen in the following issues: issue of wa'd (promise), issue of underwriting surplus, issues in the choice of takaful models, issues about the sources of capital, issues surrounding the type of risk deemed acceptable in Takaful, issues surrounding Wakala fees and the cost of capital. $70 \%$ respondents have argued that it has negative impact on the smooth operation of takaful industry.

iii. Lack of regulatory and legal framework

In the absence of standardization of a global Takaful regulatory regime, the industry is relying heavily on the opinion of the Shariah boards of the Takaful companies, subject to any local regulatory constraints. In Bangladesh, there is no specific legal framework for takaful. Islamic insurance operates under a conventional legal framework. $85 \%$ of respondents are of the opinion that lack of regulatory and legal framework is a major problem of takaful industry in Bangladesh.

\section{iv. Shortage of Shariah-compliant assets}

Takaful products reveal themselves in emerging markets and as such, Takaful faces challenge as shortage of tradable Shariah-compliant assets in the market. $85 \%$ of sample respondents are of the opinion that there is lack of Shariah-compliant assets.

\section{b. Technical issues and challenges}

The technical issues and challenges are as follows: 

i. Riba
ii. Issues around re-takaful
iii. Too much stress on profit distribution
iv. Lengthy procedure in claim's settlement

Although the Takaful practices are free from the elements of riba, but their operations so far have been limited to a few investors and to a small area. All the practices are evolved around the elements of mudarabah, tabarru and other shariah justified elements. $75 \%$ of respondents are of the opinion that it is difficult to convince general investors that they too are free from the interest unlike the conventional insurance system. Because the donation is similar to the premium the way it is calculated and enforced in the conventional insurance industry.

\section{ii. Issues surrounding Retakaful}

There is a lack of capacity within the Takaful industry for reinsurance. Therefore, a certain proportion of risk is placed with the international reinsurance companies that operate on the conventional basis. $95 \%$ of respondents are of the opinion that it is a great problem for the industry.

\section{iii. Too much stress on profit distribution}

Since only profit motive is the main concern of the conventional insurance companies, they provide generally more profit than the takaful. It presses too much stress on profit distribution that hampers the social corporate responsibilities (CSR) activities. Only 35\% respondents have argued that it is a problem for the takaful industry.

\section{iv. Lengthy procedure in Claim's settlement}

There is the lengthy procedure and time consuming in claim's settlement in takaful industry in Bangladesh.75\% of the respondents are of the opinion that lengthy procedure in claim settlement hampers the goodwill of the industry.

\section{Conclusion and suggestions}

Islamic insurance companies can provide efficient takaful services to the nation if they are supported with appropriate insurance laws, and regulations. This will help those introducing wakalah, mudarabah, ju'alah and waqf modes of operations, which are very much conducive to economic development. It would be better if Islamic insurance companies had the opportunity to work as a sole system in an economy. That would provide takaful system to fully utilize its potentials. Studies show that Islamic insurance companies cannot operate with its full efficiency level if it operates under a conventional insurance framework. The conventional system puts obstructions to efficient operations of takaful industry. However, takaful has already contributed a lot to the national economy of the country. It is still a small industry but has the potentiality to increase the size of the national takaful business. There is still a great deal of work needed to increase its awareness.

Since the educational structure in Bangladesh is not supportive for the development of Islamic finance, Bangladesh Insurance Academy(BIA) should undertake the various programs related to Islamic finance for educating the people to make them knowledgeable and qualified in the takaful issues. The takaful industry should introduce innovative products to attract more customers especially non-muslims and the industry also should introduce micro takaful to provide for the needs of the rural market.

\section{References}

Abouzaid.Chakib. (2007), "Takaful market: the challenges of the fast growing industry", MIR Takaful Market, www.meinsurancereview.com, September 2007, p- 71.

Ahmad M.S. (2007), "Takaful in South East Asia: The Growing Pains and challenges?" Kula Lumpur, Malaysia: ICMIF Takaful, No. 11.

Ali K. M, Mortuza. (2008), "Present Scenario and Future Potentials of Takaful”, Prime Life Insurance Limited, Bangladesh. P-2 at plicl@bdonline.com.

Bhatty. Ajmal. (2010), "The growing importance of takaful insurance”, Asia regional seminar organized by OECD and Bank Negara Malaysia under the sponsorship of the Government of Japan, Kuala Lumpur, 2324 Sept 2010, p-6.

Dirrheimer D. Manfred J. \& Jaffer Sohail. (2006), "Takaful Industry: Global Challenges and Opportunities", FWU Group's Solutions, m.dirrheimer@fwugroup.com.

Divanna, Joshep, Shreih, Antoine (2009), "A new financial dawn: the rise of Islamic finance", Leonardo and Francis Press Ltd, U.K. 
Drucker, P.F. (1968), The Practice of Management, Pan, 1968, pp.99-100.

ISRA (2011), "Islamic Financial System: Principles \& Operations", International Shariah Research

Academy for Islamic Finance (ISRA) publications, 2011, p-534.

Lim. Jacky, Idris.M.Fahim\& Carissa.Yura, (2010), "History, Progress and future Challenges of Islamic

Insurance (Takaful) in Malaysia”, 2010 Oxford Business \& Economics Conference Program, June 28-29,

2010, St. Hugh's College, Oxford University, Oxford, UK.

Swartz.Nico.P. \&Coetzer.Pieter. (2010), "Takaful: An Islamic insurance instrument”, Journal of

Development and agricultural Economics, Vol. 2(10), p-336.

Annual Reports:

Prime Islami Life Insurance Ltd.: (2007-2011)

Islamic Insurance Bangladesh Limited: (2007-2011)

Fareast Islami Life Insurance Company Limited : (2007-2011)

Takaful Islami Insurance Limited: (2007-2011)

Padma Islami Life Insurance : (2007-2011)

Websites:

Prime Islami Life Insurance Ltd.: www.primeislamilifebd.com

Islamic Insurance Bangladesh Limited: www.islamiinsurance.com

Fareast Islami Life Insurance Company Limited : www.fareastislamilife.com

Takaful Islami Insurance Limited: www.takaful.com.bd

Padma Islami Life Insurance : www.padmalife.com

\section{Copyrights}

Copyright for this article is retained by the author(s), with first publication rights granted to the journal.

This is an open-access article distributed under the terms and conditions of the Creative Commons Attribution License (http://creativecommons.org/licenses/by/4.0/). 